\title{
PARAMETRIKUS BIZONYTALANSÁGELEMZÉSI MÓDSZEREK ANYAGVIZSGÁLATI SZEMLÉLTETÉSE
}

\section{DEMONSTRATION OF PARAMETRIC UNCERTAINTY INVESTIGATION METHODS BY A MATERIALS TESTING EXAMPLE}

\author{
Nagyné Halász Erzsébet ${ }^{1}$, Pokorádi László ${ }^{2}$ Stein Vera ${ }^{3}$ \\ ${ }^{1}$ Óbudai Egyetem, Bánki Kar, Anyagtudományi és Gyártástechnológiai Intézet, \\ H-1081, Magyarország, Budapest, Népszínház utca, 8.; +36 16665315 , \\ nagynei.halasz@bgk.uni-obuda.hu \\ ${ }^{2}$ Óbudai Egyetem, Mechatronikai és Jármütechnikai Intézet \\ H-1081, Magyarország, Budapest, Népszínház utca, 8.; +36 309194929, \\ pokoradi.laszlo@bgk.uni-obuda.hu \\ ${ }^{3}$ Óbudai Egyetem, Mechatronikai és Jármütechnikai Intézet H-1081, Magyarország, \\ Budapest, Népszinház utca, 8.; stein.vera@bgk.uni-obuda.hu
}

\begin{abstract}
During engineering measurement and calculations parametric uncertainty can be seen that can be modeled and is described by appropriate mathematical methods and tools. One of the aims of material testing is the surface's micro-hardness determination. This study describes the main mathematical methods for describing the parametric model uncertainties and they are illustrated through an example of material testing.

Keywords: model uncertainty, parameter anomaly, materials testing

\section{Összefoglalás}

A mérnöki mérések és számítások során parametrikus bizonytalanság tapasztalható, mely megfelelő matematikai módszerekkel modellezhető és leírható. Az anyagvizsgálati eljárások egyik célja lehet a fémek, fémfelületek mikro-keménységének megfelelő pontosságú meghatározása. A tanulmány a parametrikus modellbizonytalanságot leíró főbb matematikai módszereket mutatja be és szemlélteti azokat egy anyagvizsgálati példán keresztül.
\end{abstract}

Kulcsszavak: modell bizonytalanság, paraméter-eltérés, anyagvizsgálat

\section{Bevezetés}

A bizonytalanság vizsgálata során, annak forrása alapján, megkülönböztetünk ismereti (angol nevén: ,epistemic”), és parametrikus (,parameter uncertainty") bizonytalanságot.

$\mathrm{Az}$ ismereti bizonytalanság szubjektív bizonytalanságként szemlélhetö. Ezek az okok magukba foglalhatják például a megfelelő információk, fizikai ismeretek hiányát, melyek megakadályozhatják a helyes modell felállítását.

A parametrikus bizonytalanság elsődlegesen az objektivitáshoz kapcsolható, és megfelelő módszerekkel modellezhetö, 
feldolgozható.

Tanulmányunk célja az alapvető parametrikus bizonytalanságelemzési módok anyagvizsgálati példával történő szemléltetése.

A tanulmány az alábbi részekből áll: A 2. fejezet a parametrikus modell bizonytalanságelemzési módszereket írja le röviden. A 3. fejezet egy mikro-keménységmérési példán szemlélteti az elemző eljárásokat. A 4. fejezet összegzi a tanulmány elkészítésekor szerzett tapasztalatokat.

\section{A modellek parametrikus bi- zonytalansága}

A parametrikus bizonytalanság tudományos szintü elemzése alapvetően két eltérő módon oldható meg [4]. Ezeket szemlélteti az 1. ábra „második sora”.

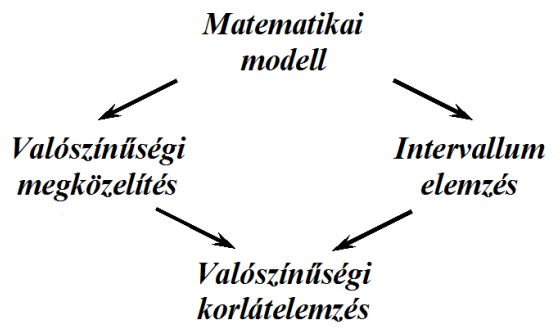

1. ábra. Bizonytalanságelemzési módszerek

Az első mód a gerjesztések bizonytalansága következtében fellépő lehetséges rendszerválaszok meghatározása intervallum értékekkel. Ezen eljárási mód annak figyelembevétele, hogy néhány, vagy az összes független paraméter nem egy adott értékkel rendelkezik, hanem bizonyos intervallumon belül található. Általános megfogalmazásuk esetén az intervallumokhoz nem kapcsolunk valószínüségi eloszlásokat, csak a lényegi eredmények lehetséges jövőbeli szélső értékeit határozzuk meg.

A valószínüségi módszere a környezet gerjesztéseinek minden lehetséges eleméhez valamilyen valószínüségi eloszlást rendel. A lehetséges rendszerválaszokhoz tör- ténő valószínűségek rendelése egy általánosan alkalmazott gyakorlat. Ilyenkor az sem ritka, hogy úgynevezett szubjektív valószínüségekkel találkozunk, ami szakértők (vagy bizonyos esetekben laikusok) által becsült valószínüségi értéket jelent.

Általában, ha az adatok valószínüségi eloszlásai ismertek, elméletileg mindegyik alternatíva következményeinek eloszlását megtudhatjuk. Ez egy egyszerü kritérium esetén a vizsgált rendszer vagy folyamat kvalitatív tulajdonságának valószínüségi eloszlását jelenti.

Például egy determinisztikus matematikai modell esetén, amikor a modell bemenő és belső jellemzői valamilyen bizonytalansággal bírnak a kalkuláció során használt valós értékü mennyiségekkel kapcsolatban, a bizonytalanságelemzés intervallumelemzéshez vezethet.

A valószínüségi módszerek egyik legelterjedtebb formája a Monte-Carlo-szimuláció, mellyel részletesebben Pokorádi és Molnár [4] publikációjukban foglalkoznak.

\section{A szemléltető példa}

A fentiekben elvben leírt parametrikus bizonytalanságelemzési eljárásokat - terjedelmi okok miatt röviden - Kovács-Coskun [1] és [2] publikációiban ismertetett vizsgálatai során végzett méréseinek eredményeit használtuk fel. A mérési eredményeket az 1. táblázat szemlélteti.

Vickers-keménység (HV) keménységmérést $136^{\circ}$-os csúcsszögü négyzet alapú gyémántgúlának $F$ terheléssel a tárgy felületébe való benyomása útján végzik úgy, hogy a közel négyzetes lenyomat két átlóját mérik és azok középértékébő1 $(d)$ számítják a lenyomat felületét.

Mivel a gyémánt gúla csúcs fél szöge $\alpha$ $=68^{\circ}$, azaz $\sin \alpha=0,9272$, ekkor a

$$
H V=\frac{1,854 F}{d^{2}}
$$

egyszerü modellt tudjuk alkalmazni, ahol: $F$ - a terhelö erő, $k p$-ban; 
$d$ - a négyszög lenyomat két átlójának számtani közepe $\mu m$-ben [3].

1. táblázat. Mérési eredmények

\begin{tabular}{|c|c|c|}
\hline Sorszám & $\begin{array}{c}\text { Mért átló } \\
d[\mu m]\end{array}$ & $\begin{array}{c}\text { Statisztikai } \\
\text { adatok } \\
{[\mu \mathrm{m}]}\end{array}$ \\
\hline 1 & 114,0 & \multirow{8}{*}{$\begin{array}{l}\text { Átlag: } 107,9 \\
\text { Szórás: } \\
4,34 \\
\text { Maximum: } \\
114\end{array}$} \\
\hline 2 & 111,0 & \\
\hline 3 & 102,6 & \\
\hline 4 & 106,3 & \\
\hline 5 & 102,0 & \\
\hline 6 & 105,3 & \\
\hline 7 & 108,3 & \\
\hline 8 & 112,6 & \\
\hline 9 & 112,0 & \multirow{4}{*}{$\begin{array}{l}\text { Minimum: } \\
102\end{array}$} \\
\hline 10 & 112,3 & \\
\hline 11 & 103,3 & \\
\hline 12 & 105,0 & \\
\hline
\end{tabular}

Ha az 1. táblázat átlagát $(107,9 \mu \mathrm{m})$ számoljuk, akkor a vizsgált munkadarab Vikers-keménysége egészszámra kerekítve: 32 .

Intervallumelemzés esetén viszont a maximális $(114 \mu \mathrm{m})$ és minimális $(102 \mu \mathrm{m})$ értékeket kell vizsgálnunk a keménység lehetséges értékei intervallumának meghatározásához. Ekkor azt tudjuk mondani, hogy a vizsgált munkadarab Vikerskeménysége a

$$
29 \sim 36
$$

intervallumba esik.

A valószínűségi megközelítés esetén az 1. táblázat adatainak elemzésével megállapított átlag és szórás felhasználásával - a kis mintaszám miatt - normál eloszlást feltételezve, például Monte-Carloszimulációval határozzuk meg a vizsgált munkadarab Vickers-keménységének eloszlását.

A szimulációhoz használt átmérők hisztogramját a 2., az így kapott Vickerskeménységek hisztogramját pedig a 3. ábra szemlélteti.

A valószínüségi megközelítés hibája, hogy a felhasznált valószínűségi eloszlások nem veszik figyelembe a valós mérnöki lehetőségeket. Például, tisztán matematikai megközelítéssel - bizonyos valószínüséggel - lehetséges a negatív átmérőjü tengely is. Ezt a hiányosságot küszöbölhetjük ki a valószínűségi korlátelemzés alkalmazásával. Esetünkben a Monte-Carlo-szimulációhoz a mért adatok minimum és maximum értékei alapján - a „közkedvelt” $3 \sigma$ szabályt alkalmazva határozzuk meg az alkalmazandó normál eloszlás várható értékét (a minimum-maximum intervallum közepe) és szórását (az intervallum „hosszának” hatoda).

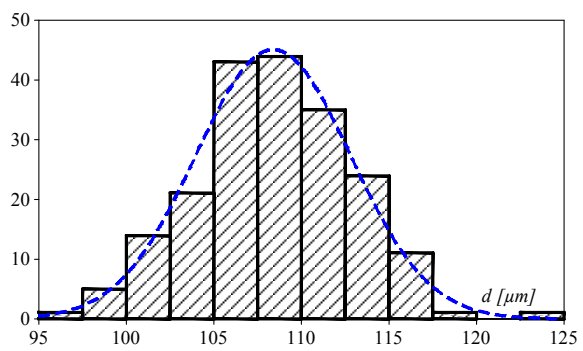

2. ábra. Valószinüségi megközelités gerjesztéseinek hisztogramja

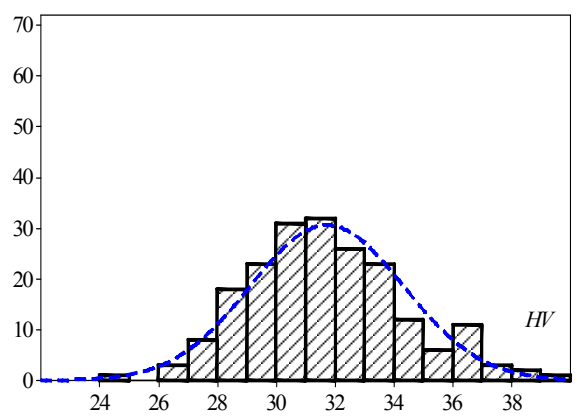

3. ábra. Valószinüségi megközelités válaszainak hisztogramja

A valószínüségi korlátelemzéssel elvégzett szimulációhoz használt átmérök hisztogramját a 4. ábra, az így kapott Vickerske-ménységek hisztogramját pedig az 5. ábra szemlélteti. 


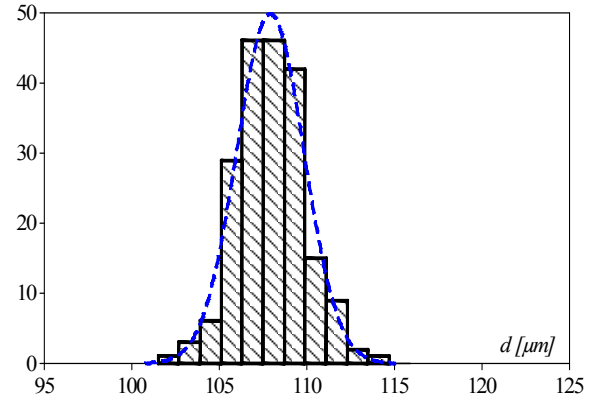

4. ábra. Valószinüségi korlát megközelités gerjesztéseinek hisztogramja

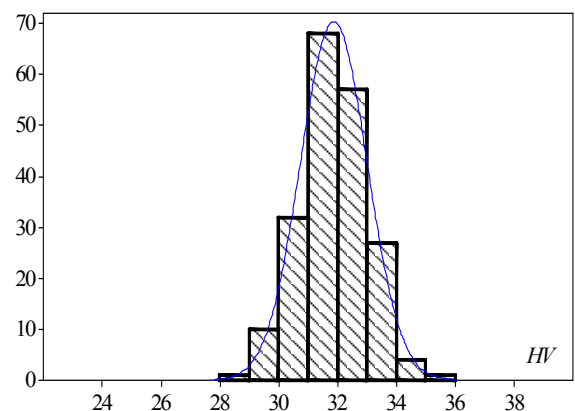

5. ábra. Valószinüségi korlát megközelités válaszainak hisztogramja

Vessük össze a kapott eredményeket!

Ha „csak” a mérési eredmények átlagával határoztuk meg a munkadarab keménységét, egyetlen értéket kaptunk. Az eredmény bizonytalanságától nem szereztünk információt. Ne feledjük, hogy a értékeit mindig egész számmal fejezzük ki. Esetünkben pont fel is tehetjük Mátyás király híres kérdését: Hány még a harminckettö?

$\mathrm{Az}$ intervallumbecslés alkalmazása esetén már tudjuk, hogy a 32 akár, 29 vagy 36 is lehet.

A valószínüségi megközelítés alapján már egy eloszlást is tudhatunk arról, hogy mennyi a 32. Viszont azt is beláthatjuk, hogy a matematikailag lehetséges értékek mérnöki lehetetlenségeket is takarhatnak (lásd 2. és 3. ábrákat).
Ezért alkalmaztuk a valószínüségi korlátelemzést. Figyelembe vettük azt, hogy a mért paraméterek valamilyen valószínüségi eloszlással bírnak. De azt is figyelembe vettük, hogy ezen eloszlásoknak valós, fizikai korlátai vannak. Ez utóbbi megközelítés eredményeit szemlélteti a 4. és az 5 . ábra.

A két utóbbi elemzés eredményeinek összehasonlításakor látható, hogy a valószínüségi korlát elemzés Vickers-keménység eloszlása egy szükebb, a mérnöki valóságot jobban tükröző intervallumra koncentrálódik.

\section{Következtetések}

Dolgozatunk röviden leírta, és egy anyagvizsgálati (mikro-keménységmérési) példán keresztül szemléltette az alapvető parametrikus modell bizonytalanságelemző módszereket. A másodrendű valószínűségi megközelítés bemutatásától - terjedelmi okok miatt - jelen munkánkban eltekintettünk.

Célunk a néha csak elméleti fejtegetésnek tünő kérdéskör gyakorlati, nem csak anyagvizsgálati, mérnöki példával való bemutatása, értelmezése.

\section{Szakirodalmi hivatkozások}

[1] Kovács-Coskun, T., Völgyi B., Sikari-Nágl I: Investigation of aluminium-steel joint formed by explosion welding. Journal of PhysicsConference Series 602, 2015, 1-4.

[2] Kovács-Coskun T.: Explosive Surface Hardening of Austenitic Stainless Steel, IOP Conference Series: Materials Science and Engineering123, 2016, 1-5.

[3] Nagyné Halász, E.; Pokorádi L.: Parametrikus modellbizonytalanság: egy anyagvizsgálati példa, A XXI. Fiatal Mủszakiak Tudományos Ülésszaka előadásai, Kolozsvár, 2016, 293-296.

[4] Pokorádi L.; Molnár B.: A Monte-Carlo szimuláció szemléltetése, Szolnoki Tudományos Közlemények XIV, 2010, 1-12. 